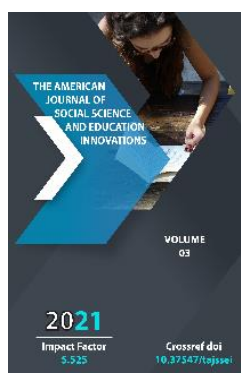

\section{Historical Aspects Of The Environmental Policy Strategy In The Field Of Sustainable Development Of The Southern Aral Sea Region At The Present Stage}

\author{
A.Kaipnazarov \\ Assistant, The Department Of History Nukus State Pedagogical Institute Named After \\ Ajiniyaz, Uzbekistan \\ Email: Kaypnazarov8o@ndpi.uz
}

Copyright: Original content from this work may be used under the terms of the creative commons attributes 4.0 licence.

\title{
ABSTRACT
}

The article discusses the issues related to the solution of problems to improve the situation in the Aral Sea basin, which also included measures to save the Aral Sea region. In order to strengthen mutual understanding and trust between all Central Asian countries and establish openness in relations, the Republic of Uzbekistan considers it necessary to undertake joint efforts to find mutually beneficial solutions to resolve the issue of rational and fair use of water resources in Central Asia.

\section{KEYWORDS}

Priaralye, regional development program, rational use of resources, phytomelioration.

\section{INTRODUCTION}

The tragedy of the disappearance of the Aral Sea is one of the most convincing and vital arguments against the unbalanced and not designed for sustainability actions committed by the human race, of which there were so many during both the creative and at the same time destructive second half of the XX century.
During this half-century period, humanity has not only reached the heights of technological development, but also caused damage to nature more than ever before. Thanks to the agreements adopted between various states and the participation of international funds and the World Bank, practical measures are being 
implemented and bring positive results to mitigate the impact of the environmental crisis on the health of the Aral Sea population and improve ecosystems $[1,4,9]$.

The understanding of the need to do something in conditions when the Aral Sea began to dry up quickly came to Soviet society in the early 70s, when several government commissions were created, which gave conclusions on the need for urgent measures, if not to stop the decline in sea level then, at least, to prevent negative socio-economic and environmental phenomena associated with this disaster. As such a measure, a proposal was put forward on additional supply of Siberian River to the region in the amount of 18$20 \mathrm{~km} 3$ per year to improve water supply and at the same time to improve the situation in the Aral Sea region [2, 7]. In 1986, this proposal was rejected by the Government of the USSR and, as opposite measures, a set of measures approved by Decree No. 1110 in 1986 was proposed, as a result of which two BWOs "Syrdarya and Amudarya", a special organization "Aralvodstroy" and a coordinator from the program - the consortium "Aral" [7].

\section{THE MAIN FINDINGS AND RESULTS}

During 1987-1990, a certain amount of work was carried out to improve water saving in the Aral Sea region, along the Right-Bank collector, upon completion of the construction of the Tuyamuyun reservoir, etc. In 1991, after the collapse of the USSR, all these works were stopped until the heads of state of the five countries in 1993 created the International Fund for Saving the Aral Sea and on January 11, 1994, they approved a plan of priority measures to improve the situation in the Aral Sea basin, which included measures to save the Aral Sea region $[2,3,6]$. In particular, at this meeting, it was decided to "study and develop engineering solutions for drafting projects, carrying out work to create artificially flooded landscape ecosystems in the Amu Darya and Syr Darya deltas and adjacent areas of the Aral Sea drained day and carry out the necessary reclamation measures to restore natural history regime and rehabilitation of these territories". At the same time, the "Basic provisions of the concept of improving the socio-economic and ecological situation in the Aral Sea region" were approved, which emphasized the impossibility of restoring the Aral Sea in its original state and at the same time focused on the need to implement a complex of structures, forest and water reclamation works, as well as measures aimed at creation of a new natural-anthropogenic sustainable ecological profile of the Aral Sea region by means of water supply, forest reclamation and other works and projects $[3,6$, 8].

August 29, 2015 The Cabinet of Ministers of the Republic of Uzbekistan adopted a Resolution "On a comprehensive program of measures to mitigate the consequences of the Aral Sea disaster, recovery and socio-economic development of the Aral Sea region for 20152018," which provides for the implementation of projects with a total cost of US $\$ 3.9$ billion in five main areas: economical use water resources and improving their management, creating conditions for the implementation of measures to preserve the gene pool and protecting the health of people living in an ecologically dangerous territory, developing the necessary economic factors and mechanisms to improve the level and quality of life of the Aral Sea population, protecting and preserving the flora and fauna, restoring ecosystems and biodiversity $[1,3,5]$. Also on 
January 18, 2017, By a decree of the President of the Republic of Uzbekistan, the State Program for the Development of the Aral Sea Region for 2017-2021 was approved, aimed at improving the conditions and quality of life of the population of the region, providing for the implementation of projects with a total value of 8.422 trillion soums [10].

The program includes measures to create new jobs, increase the investment attractiveness of the region, develop water supply, sewage systems, sanitation and waste disposal, improve health care, housing conditions for the population, landscaping, create children's and sports grounds, develop transport, engineering and communication infrastructure of settlements, improvement of heat supply systems in Nukus and Urgench.

However, taking into account the planetary nature of the Aral Sea disaster, it is necessary to expand joint actions with the world community in this direction through the implementation of deeply thought-out, targeted projects and provided with appropriate sources of funding.

The Republic of Uzbekistan believes that the issue of using the water resources of Central Asia should be considered in accordance with the generally recognized norms of international law, which guarantee a rational and equitable distribution of water resources, and ensure that the interests of all states of the region are taken into account.

Considering that currently Uzbekistan, like other Central Asian countries located in the lower reaches of transboundaryriver is experiencing a serious shortage of water resources, the position of the Uzbek side on the use of transboundary water resources in Central Asia is as follows:
- Issues of using water resources of transboundary rivers in Central Asia should be resolved taking into account the interests of more than 60 million people living in all countries of the region;

- Any actions taken on transboundary rivers should not have a negative impact on the existing ecological and water balance of the region;

- The current international legal framework in the field of water use and ecology should become the basis for building an effective system for the joint use of resources of transboundary rivers in Central Asia;

- The implementation of projects should be carried out on the basis of a constructive approach and a compromise, in which the interests of other interested states are not infringed and two necessary conditions are guaranteed: not to allow a decrease in the level of the watercourse water balance agreed by the parties for countries located downstream; not disturbing the ecological balance of the region.

In order to strengthen mutual understanding and trust between all Central Asian countries and establish openness in relations, the Republic of Uzbekistan considers it necessary to undertake joint efforts to find mutually acceptable and mutually beneficial solutions to resolve the issue of rational and fair use of water resources in Central Asia [6, 8]. Since 1998, work has begun to revive the wetlands of the Amu Darya delta at the expense of the contributions of the Republic of Uzbekistan to IFAS and funds from donor states. As a result, such reservoirs as Muynak, Rybachye, as well as lakes Dumalak, Karadzhar, Sudochye, Imenkul, Mashankul, Zhiltyrbas, Maypost and others were formed. 
The above measures to preserve the ecosystem of the Aral Sea region contributed to the stabilization and restoration of biota in the region. In order to assess the effectiveness of the ongoing rehabilitation measures in this region, it is also necessary to establish regular monitoring of flora and fauna species.

Speaking about the humanitarian dimension of the UN, that human security is the most important object of its activity in the modern era, the countries directly adjacent to the Aral Sea zone would like this understanding to find a more concrete embodiment in solving the Aral Sea crisis. It must be borne in mind that today we are not talking about saving the Aral Sea, but about stopping those negative trends that can lead to irreversible changes in the lives of people living in the region. The task is "not to save water", but to solve the problems of rehabilitation of the Aral Sea region, preserving the health and gene pool of the population, restoring and protecting ecosystems, creating all the necessary conditions for a decent life for people.

\section{CONCLUSION}

Thus, with regard to the Aral Sea region, apparently, the main efforts should be directed at ensuring the supply of high-quality water to the population by the available water pipelines in the required volumes (since there are still interruptions, often for technical reasons); it is significant to control the rational use of river runoff waters on the territory of deltas, as well as the direction of used waters to the sea. To reduce the negative impact of the dried seabed on the adjacent territories of the Aral Sea region in Karakalpakstan, it is planned to continue work on its phytomelioration. It also contributes to the increase in employment of the population. Undoubtedly, further, more radical restructuring of the economy in this territory is also necessary to ensure employment of the population, improve the ecological, medico-biological and sanitaryhygienic situation.

The problem of attracting additional water to solve the Aral issue and to manage the economy in the Central Asian region remains relevant primarily to meet drinking needs in a relatively small volume. Nevertheless, it is necessary to continue research and development of various ways to solve the Aral Sea problem using modern innovative technologies.

\section{REFERENCES}

1. Akramov Z., Rafikov A. 1990. Past, present, future of the Aral Sea / Ed. ON. Krivonosov. Tashkent: MECHNAT. $-\mathrm{p}$. 144.

2. Aladin N.V., Gontar V.I., Zhakova L.V., Plotnikov I.S., Smurov A.O. 2018. Prospects for the biodiversity of the Aral Sea // Collection of materials of the international conference: "Joint actions to mitigate the consequences of the Aral disaster: new approaches, innovative solutions and investments. Tashkent, June 7-8, 2018 Tashkent. -pp. 114-120.

3. Integrated remote sensing and ground-based studies of the drained bottom of the Aral Sea. 2008 // Ed. V.A. Dukhovny, P. Navratila, I. Ruziev, G. Stulin, I. Roshchenko. Tashkent: SIC ICWC. -pp. 190.

4. Interstate Commission for Water Coordination of Central Asia. 2018. [Electronic resource http://www.icwcaral.uz/cmc_ru.htm (date of treatment 
07/23/2018)]. ICWC 1992/2002. 2002.

Advertising brochure. -p. 16.

5. A new project for phytomelioration in the lower reaches of the Amudarya delta and on the dried seabed. 2018. [Electronic resource http://www.cawater-info.net/bestpractices/ru/base/marker/177 (date of access 12.12.2018)].

6. On measures to radically improve the ecological and sanitary situation in the Aral Sea region, increase the efficiency of use and strengthen the protection of water and land resources in its basin. 1988. Resolution of the Central Committee of the CPSU, USSR Council of Ministers of 09/19/1988 N 1110 (Electronic resource https://ipravo.info/sssr1/laws/553.htm [Date of treatment 01/12/2019]).

7. Ecological research and monitoring of the Aral sea deltas: a basis for restoration. 2001. Book 2. Paris: UNESCO. -p. 284.

8. Kuz'mina Zh.V., Treshkin S.Ye. 2013. Monitoring of Growth of Black Haloxylon (Haloxylon aphyllum) on Hydromorphic Salt Marches of Dried Bottom of Aral Sea // Arid Ecosystems. Vol. 3. No. 4. pp. 220-226.

9. Vostokova E.A. 1999. Ecological disaster linked to landscape composition changes in the Aral sea basin // Creeping environmental problems and sustainable development in the Aral sea basin. 1999 / Ed. M.H. Glantz. Cambridge univ. press. P. 26-46.

10. Resolution of the President of the Republic of Uzbekistan dated January 18, 2017 No. PP-2731 “On the State Program for the Development of the
Aral Sea Region for 2017-2021" // "Collection of Legislation of the Republic of Uzbekistan", Tashkent. January 30, 2017, No. 4, art. 49 